\title{
Parvalbumin-Expressing Inhibitory Interneurons in Auditory Cortex Are Well-Tuned for Frequency
}

\author{
Alexandra K. Moore and Michael Wehr \\ Institute of Neuroscience, University of Oregon, Eugene, Oregon 97403
}

In the auditory cortex, synaptic inhibition is known to be involved in shaping receptive fields, enhancing temporal precision, and regulating gain. Cortical inhibition is provided by local GABAergic interneurons, which comprise $10-20 \%$ of the cortical population and can be separated into numerous subclasses. The morphological and physiological diversity of interneurons suggests that these different subclasses have unique roles in sound processing; however, these roles are yet unknown. Understanding the receptive field properties of distinct inhibitory cell types will be critical to elucidating their computational function in cortical circuits. Here we characterized the tuning and response properties of parvalbumin-positive $(\mathrm{PV}+)$ interneurons, the largest inhibitory subclass. We used channelrhodopsin-2 (ChR2) as an optogenetic tag to identify PV + and PV - neurons in vivo in transgenic mice. In contrast to PV + neurons in mouse visual cortex, which are broadly tuned for orientation, we found that auditory cortical PV + neurons were well tuned for frequency, although very tightly tuned PV + cells were uncommon. This suggests that PV + neurons play a minor role in shaping frequency tuning, and is consistent with the idea that $\mathrm{PV}+$ neurons nonselectively pool input from the local network. $\mathrm{PV}+$ interneurons had shallower response gain and were less intensity-tuned than PV - neurons, suggesting that $\mathrm{PV}+$ neurons provide dynamic gain control and shape intensity tuning in auditory cortex. PV + neurons also had markedly faster response latencies than PV- neurons, consistent with a computational role in enhancing the temporal precision of cortical responses.

\section{Introduction}

The responses of neurons in the auditory cortex are powerfully shaped by the relative strength and timing of excitatory and inhibitory synaptic inputs. Cortical inhibition is provided by local GABAergic interneurons, which comprise $\sim 20 \%$ of the cortical population (Xu et al., 2010; but see Meyer et al., 2011) and can be separated into numerous subclasses (DeFelipe, 1997; Markram et al., 2004). Striking differences in the postsynaptic targets of these inhibitory subtypes suggest that they are specialized to perform different computational functions (Isaacson and Scanziani, 2011; Fino et al., 2013). Pharmacological and whole-cell voltage-clamp studies have indicated important computational functions for cortical inhibition, such as shaping receptive fields, enhancing temporal precision, and providing gain control (Wang et al., 2002b; Wehr and Zador, 2003; Tan et al., 2004; Wu et al., 2006). However, these methods lump together all sources of synaptic inhibition, and thus cannot reveal the distinct contributions of specific subtypes of inhibitory neurons. To reveal their specific contributions, direct measurement of the tuning properties of each inhibitory cell type is necessary.

Here we investigated the tuning properties of a genetically identified class of interneurons, those expressing parvalbumin

Received Feb. 1, 2013; revised July 9, 2013; accepted July 12, 2013.

Author contributions: A.H. and M.W. designed research; A.H. performed research; A.H. analyzed data; A.H. and M.W. wrote the paper.

This work was funded by the Whitehall Foundation and the NIH.

The authors declare no competing financial interests.

Correspondence should be addressed to Dr Michael Wehr, Institute of Neuroscience, 1254 University of Oregon, Eugene, 0R 97403. E-mail: wehr@uoregon.edu.

DOI:10.1523/JNEUROSCI.0663-13.2013

Copyright $\odot 2013$ the authors $\quad 0270-6474 / 13 / 3313713-11 \$ 15.00 / 0$
$(\mathrm{PV}+) . \mathrm{PV}+$ interneurons account for $\sim 40 \%$ of the GABAergic population (Xu et al., 2010). Most PV+ neurons are chandelier and basket cells, which make powerful inhibitory synapses onto the somatic and perisomatic regions of pyramidal cells. PV + cells are therefore likely to have a profound impact on the spiking output of their targets. To gain insight into their computational role, here we ask whether and how the response properties of $\mathrm{PV}+$ neurons differ from those of $\mathrm{PV}-$ neurons, which are primarily excitatory pyramidal cells.

In mouse visual cortex, $\mathrm{PV}+$ neurons are more broadly tuned for orientation than pyramidal neurons (Ma et al., 2010; Kuhlman et al., 2011; Zariwala et al., 2011; Wilson et al., 2012; but see Runyan et al., 2010). Their broader tuning is proposed to arise from unbiased pooling of excitation from local pyramidal neurons with heterogeneous orientation tuning (Kerlin et al., 2010; Hofer et al., 2011). This principle provides a possible explanation for why PV+ neurons are broadly tuned in mice, which lack orientation columns, but are narrowly tuned in higher mammals, which do have orientation columns (Hirsch et al., 2003; Cardin et al., 2007; Nowak et al., 2008). If this principle generalizes across sensory modalities, PV+ neurons in mouse auditory cortex should be well tuned for frequency, because it has tonotopically organized frequency columns.

To test this hypothesis, we compared the receptive fields and other response properties of $\mathrm{PV}+$ and $\mathrm{PV}-$ neurons in mouse auditory cortex. We used an optogenetic tag to identify PV + and $\mathrm{PV}$ - neurons in ChR2-expressing transgenic mice (Lima et al., 2009). We found that the tuning widths of layer II-VI PV+ and $\mathrm{PV}-$ cells were not significantly different, although very tightly tuned PV+ cells were rare. Overall, PV + response properties 
were similar to those of PV- cells, with a few exceptions: PV+ cells had comparatively higher evoked and spontaneous firing rates, shorter response latencies, and more monotonic rate-level functions at their characteristic frequencies.

\section{Materials and Methods}

Animals

All procedures were in strict accordance with the National Institutes of Health guidelines as approved by the University of Oregon Animal Care and Use Committee. Neurons were recorded in heterozygous offspring (18 males, 20 females) of a cross between a cre-dependent ChR2-eYFP line (Madisen et al., 2012; JAX Stock No. 012569) and a Pvalb-IRES-Cre line (Hippenmeyer et al., 2005; JAX No. 008069). Because the ChR2eYFP fusion protein is membrane bound, we visualized Pvalb-IRES-Cre expression in auditory cortex in a cross to a cytosolic tdTomato reporter line (Madisen et al., 2010; JAX No. 007909). All genotyping was performed by the Transgenic Mouse Facility at the University of Oregon.

\section{Immunohistochemistry}

Animals were perfused transcardially with a 4\% PFA solution. Brains were postfixed overnight and cryoprotected in $30 \%$ sucrose. Thirty micrometer thaw-mounted sections were blocked in $10 \%$ normal goat serum with $0.3 \%$ Triton in PBS for $3 \mathrm{~h}$. Sections were incubated overnight in mouse antiparvalbumin (1:4000; Millipore Bioscience Research Reagents MAB1572), incubated for $4 \mathrm{~h}$ in Alexa Fluor 546 goat anti-mouse (ChR2-eYFP/PV-cre; 1:400; Invitrogen A11003) or Alexa Fluor 488 goat anti-mouse (Ai9-tdTomato/PV-cre; 1:400; Invitrogen A21121), and coverslipped with anti-fade mounting medium. To quantify expression specificity, cells were identified in independent fluorescent channels and subsequently scored for colocalization. Image intensities were equalized beforehand. Thick sections $(200 \mu \mathrm{m})$ were processed with Sca/e (Hama et al., 2011).

\section{Electrophysiology}

We recorded from the left auditory cortex of anesthetized mice, aged 2-4.5 months (anesthesia, in mg/kg: 120 ketamine, 0.24 medetomidine, 3 acepromazine). Animals received $0.25 \mathrm{mg} / \mathrm{kg}$ atropine sulfate and 20 $\mathrm{mg} / \mathrm{kg}$ dexamethasone. The surgery procedure was described previously (Tan and Wehr, 2009). For each animal we obtained a coarse map of auditory cortex, using both multiunit responses and local field potentials from the middle layers (150-450 $\mu \mathrm{m})$. We saw no evidence of C57BL/6J age-related hearing loss at these ages (Ison et al., 2007). All mice had normal sound thresholds and tonotopy (i.e., had sites with best frequency $>20 \mathrm{kHz}$ ). The cells included in our analysis were obtained in well-tuned regions of auditory cortex. Based on tonotopic gradient, most of these neurons were in A1, although a small fraction of them may have been in contiguous well tuned areas, anterior auditory field or A2 (Guo et al., 2012). Subpial recording depths were determined from micromanipulator travel.

Single-cell recordings were obtained using high-impedance (7-14 $\mathrm{M} \Omega$ ) tungsten microelectrodes (127 $\mu \mathrm{m}$ diameter, $12^{\circ}$ tapered tip, epoxy-coated, A-M Systems catalog \# 577200), which provided better isolation and yield for PV + neurons than glass or tetrode configurations. Signals were amplified with an A-M Systems 1800 or Dagan EX-1000 extracellular amplifier and bandpass filtered from 300 to $5000 \mathrm{~Hz}$. Spike times were extracted using a fixed voltage threshold exceeding $5 \mathrm{SD}$ of the baseline extracellular voltage. Single neurons were very well isolated, with a mean signal-to-noise ratio of $25.8 \pm 23.4$, median 17.9.

\section{Light stimuli, optical identification of $P V+$ neurons}

$\mathrm{PV}+$ cells were identified with a $30 \mathrm{~ms}$ light pulse search stimulus (interstimulus interval $500 \mathrm{~ms}$ ). Light was delivered from a custom-built fibercoupled LED (wavelength $470 \mathrm{~nm}$, fiber diameter $800 \mu \mathrm{m}$ ). The fiber tip was positioned several millimeters above the recording site using a micromanipulator. Light power was $\sim 5 \mathrm{~mW} / \mathrm{mm}^{2}$ at the cortical surface. Robust light-evoked multiunit activity in deep layer $6(800-850 \mu \mathrm{m})$ indicated that this power was sufficient to drive PV+ neurons throughout the depth of cortex.

$\mathrm{PV}+$ cells responded to $30 \mathrm{~ms}$ light pulses with a reliable, short-latency burst of spikes and showed sustained spiking responses to longer $(>100$ ms) light pulses. PV - cells were obtained in the same animals and did not respond to light. Light-evoked spikes were readily distinguishable from transient light artifacts at the onset and offset of the light pulse, because spikes were much greater in amplitude (mean spike-to-artifact amplitude ratio, $9.77 \pm 10.7$ ) and spiking persisted for the duration of the pulse. All spikes analyzed in this report were collected in the absence of light stimulation (i.e., were either spontaneous or sound-evoked spikes) except for the example shown in Figure $1 a$.

\section{Acoustic stimuli}

Sounds were delivered from a free-field speaker facing the contralateral ear. We calibrated the speaker to within $\pm 1 \mathrm{~dB}$ using a Brüel and Kjær $49391 / 4$ " microphone positioned where the ear would be, without the animal present. Acoustic stimuli were $25 \mathrm{~ms}$ pure tones or white noise (WN), with $3 \mathrm{~ms} 10-90 \%$ cosine-squared ramps. Stimuli were pseudorandomly interleaved with a $500 \mathrm{~ms}$ interstimulus interval. Responses were computed as the spike rate in an $80 \mathrm{~ms}$ window following sound onset and averaged across all presentations (typically 20) of the stimulus. We chose this response window to best exclude non-stimulus-evoked spikes, because PV + cells had high spontaneous firing rates. Spontaneous firing rate was computed as the firing rate of the cell in an $80 \mathrm{~ms}$ window preceding sound onset, averaged across all stimuli in the set. To determine each neuron's characteristic frequency (CF; the frequency that evoked spikes at the lowest sound level) we first obtained a coarse frequency-intensity tuning curve $(1-40 \mathrm{kHz}$ at 4 frequencies/octave, $20-80 \mathrm{~dB}$ in $15 \mathrm{~dB}$ steps, $\leq 10$ repetitions). We used this first curve for an initial estimate of CF and sound level threshold. We then obtained a more accurate estimate of CF using a custom tone array (typically 6 frequencies/octave, intensities in $10 \mathrm{~dB}$ steps, $\geq 20$ repetitions) centered on our initial CF and threshold estimates.

Rate level functions and iso-intensity tuning curves. To measure ratelevel functions, we presented $\mathrm{WN}$ and/or pure tones at $\mathrm{CF}$ at intensities of -10 to $90 \mathrm{~dB}$ in $5 \mathrm{~dB}$ steps (or in a few cases, $10 \mathrm{~dB}$ steps from 0 to $80 \mathrm{~dB}$ ). We obtained an online estimate of the intensity threshold for each cell, which was the lowest intensity that elicited a response above baseline (spontaneous firing rate +2 SEM) and for which responses remained above baseline for at least three consecutive intensity increments. We then used this value, the CF pure-tone threshold, to select the appropriate level for an iso-intensity tuning curve, which was presented $20 \mathrm{~dB}$ above threshold. Iso-intensity tuning curves consisted of pure tones from 1 to $40 \mathrm{kHz}$, sampled at 6 frequencies/octave. For quantitative analysis of sound thresholds and frequency tuning bandwidths we used offline fitting procedures (see below). Due to the constraints of recording duration, we were not able to present all stimulus arrays for all cells. Stimuli presented to our PV - sample were approximately matched to the PV+ sample. Of $68 \mathrm{PV}+$ and $72 \mathrm{PV}-$ cells, we obtained full WN rate level functions (RLFs) for $57 \mathrm{PV}+$ and $49 \mathrm{PV}-$ cells, CF RLFs for $48 \mathrm{PV}+$ and $38 \mathrm{PV}-$ cells, and iso-intensity tuning curves for $46 \mathrm{PV}+$ and 46 $\mathrm{PV}-$ cells.

\section{Analysis}

Unless stated otherwise, statistical results are reported as mean \pm SD and $p$ value, compared using the Wilcoxon rank sum test.

Waveforms. We obtained an average interpolated waveform (10X oversampled from a $10 \mathrm{kHz}$ sampling rate) for each cell from 200 spontaneous or sound-evoked spikes, aligned to peak or trough, whichever was larger. Spike width was measured from $20 \%$ of the peak to $20 \%$ of the trough. This width measure provided better separation of PV + and PVcells than did a direct peak-to-trough measurement. We also computed the peak/trough ratio and the endslope of the averaged spike waveforms (Niell and Stryker, 2008). The latter is the slope of the waveform $0.5 \mathrm{~ms}$ after the trough. Endslope reflects the duration of the slower second phase of the action potential. It tends to be negative for cells with narrow spikes and positive for cells with broad spikes.

To separate fast-spiking (FS) from regular-spiking (RS) cells based on spike width alone, we used an empirically determined value of $0.8 \mathrm{~ms}$, which was approximately halfway between the mean spike widths of our $\mathrm{PV}+$ and PV - groups and provided the best separation between them. There does not appear to be a consensus value for the extracellular FS/RS 
spike width cutoff in the literature (Atencio and Schreiner, 2008; Niell and Stryker, 2008; Wu et al., 2008) because it may depend on the choice of recording technology.

Frequency tuning width. We quantified the bandwidth of iso-intensity frequency tuning curves using $\sigma$ of a Gaussian fit to the tuning curve. To ensure that $\sigma$ was a good estimate of tuning width we excluded cells that were poorly fit by a Gaussian, using a criterion of $R^{2}<0.2$ (note that varying this value by \pm 0.2 did not affect our results, even using a criterion of $R^{2}=0$, i.e., no cells excluded), or had a best frequency that exceeded the upper frequency range of our speakers $(\mu>40 \mathrm{kHz})$. Because we could not confidently estimate the best frequency of these cells, we also excluded them from our analysis of response latency to tones at best frequency.

Response latency. We computed response latency for pure tones at best frequency and white noise, $20 \mathrm{~dB}$ above threshold. Spike times were accumulated for repeated presentations of the stimulus and smoothed by Gaussian convolution ( $\sigma=6 \mathrm{~ms}$ ). To estimate baseline spiking activity, the same was done for an $80 \mathrm{~ms}$ window preceding stimulus onset. Response latency was taken as the time at which the convolved response exceeded $50 \%$ of the poststimulus maximum, above the computed baseline. To reduce the sensitivity of latency estimates to outlier spikes, the final value for each cell was obtained by reiterating this process using one half of the trials (typically 10/20, randomly drawn). Response latency was the mean of the distribution of estimates from 1000 such subsamples. We did not impose any a priori constraints on latency values. Imposing exclusion criteria, such as the SD of the distribution exceeding $10 \mathrm{~ms}$ (CF: 6/31 PV+, 6/34 PV- excluded; WN: 9/57 PV+, 10/49 PV- excluded) or even 5 ms (CF: 10/31 PV+, 18/34 PV-; WN: 29/57 PV+, 21/49 PV-) did not change our results. We confirmed our results using an alternative latency estimation method. Latency was computed as the mode of first spike times for 20 presentations of the stimulus, with spike times rounded to the nearest millisecond.

$R L F s$. We fit each RLF with a six-parameter, two-tailed split Gaussian (Watkins and Barbour, 2011). We extracted several parameters from the fit including (1) the cell's intensity threshold (dB), (2) the dynamic range for firing rate ( $\Delta \mathrm{FR})$, and (3) the dynamic range of sound levels evoking an increasing firing rate $(\Delta \mathrm{dB}$; Watkins and Barbour, 2011). We also computed the slope of the RLF $(\Delta \mathrm{FR} / \Delta \mathrm{dB})$. To obtain these values we defined sound level threshold as $20 \%$, and saturation as $80 \%$, of the maximum response of the fitted curve. The firing rate dynamic range was computed as the difference in firing rate between threshold and saturation, and the level dynamic range as the difference in sound level between threshold and saturation, as illustrated in Figure $4 a, b$.

Monotonicity index. Monotonicity index (MI) characterizes the strength of a cell's intensity tuning. We defined MI as the neuron's response at maximum intensity ( $90 \mathrm{~dB}$ ) divided by its maximum response (Sutter and Schreiner, 1995; de la Rocha et al., 2008; Watkins and Barbour, 2011). An MI of 1 indicates no intensity tuning; an MI near zero indicates very strong intensity tuning.

\section{Results}

\section{ChR2-based identification of PV + and $\mathrm{PV}-$ cells}

We obtained single-unit extracellular recordings from optogenetically identified PV + neurons in mice that expressed ChR2 specifically in PV + cells. The mice were generated by crossing a cre-dependent ChR2-eYFP line (Madisen et al., 2012) to a PvalbIRES-Cre line (Hippenmeyer et al., 2005), whose expression specificity has been verified in cortex (Kuhlman and Huang, 2008; Runyan et al., 2010; Atallah et al., 2012). We were able to unambiguously identify PV + cells in vivo $(n=68)$ by their sustained, short latency responses to pulses of blue light (Fig. 1a; Lima et al., 2009). We collected a sample of PV - cells $(n=72)$ in the same animals, which did not respond to light. Presumably, these PV - cells were almost exclusively excitatory pyramidal cells, although a small fraction $(<12 \%$; Meyer et al., 2011; Xu et al., 2010) could have been PV - inhibitory interneurons.
More than 97\% of PV + cells expressed ChR2-eYFP, as indicated by fluorescent immunostaining for PV (Fig. $1 b ; n=657$ cells in two mice, four sections total). YFP-fluorescent somata were difficult to distinguish from neuropil because the ChR2eYFP fusion protein is membrane-bound. To better quantify the distribution of PV + cells in auditory cortex we crossed PvalbIRES-Cre to a cre-dependent tdTomato reporter line (Madisen et al., 2010). Expression specificity was similar for the cytosolic tdTomato reporter: $>97 \%$ of tdTomato-expressing cells stained positively for PV; $>96 \%$ of PV-positive cells expressed tdTomato (Fig. $1 c ; n=638$ cells in one mouse, four sections). PV + neurons were distributed widely throughout the depth of auditory cortex (Fig. 1c, layers II-VI; Cruikshank et al., 2001). The distribution of depths for our electrophysiologically recorded PV + neurons did not differ significantly from the distribution of tdTomatoexpressing cells (two-sample Kolmogorov-Smirnov test, $p>0.05)$, although neurons in deep layers were slightly underrepresented in our sample. Parvalbumin is transiently expressed in a small subset of layer $\mathrm{V}$ pyramidal neurons during development (Tanahira et al., 2009). Because Cre-mediated recombination is permanent, transient expression during development could lead to permanent ChR2 expression, even in cells that no longer express PV in adulthood. We did note that a very small subset $(<1 \%)$ of tdTomato-expressing cells in layer $\mathrm{V}$ had pyramidal-type morphology. Of our sample of 68 recorded PV+ neurons, 24 were found in layer V $(\sim 420-650 \mu \mathrm{m}$; Anderson et al., 2009) and we therefore estimate that our sample contained $<0.24$ pyramidal neurons. In other words, our PV + neurons are almost certainly exclusively PV + inhibitory interneurons.

An advantage of optogenetic identification is that we were able to sample $\mathrm{PV}+$ and $\mathrm{PV}$ - neurons from all cortical layers (depth 100-850 $\mu \mathrm{m}$; Fig. $1 d$ ). Our PV + and PV - groups had similar depth distributions $(\mathrm{PV}+: 442 \pm 184 \mu \mathrm{m}, \mathrm{PV}-: 396 \pm 175 \mu \mathrm{m}$, $p>0.05$; mean $\pm \mathrm{SD}$, Wilcoxon Rank-sum for this and subsequent tests). We sampled across the tonotopic extent of A1 for both groups; characteristic frequencies ranged from 5 to $34 \mathrm{kHz}$ (Fig. 1e), and did not differ between our PV + and $\mathrm{PV}-$ samples $(\mathrm{PV}+: 17.3 \pm 6.8 \mathrm{kHz}, \mathrm{PV}-: 18.0 \pm 8.3 \mathrm{kHz}, p>0.05)$.

\section{Extracellular waveforms}

Extracellular spike waveforms are commonly used to identify putative cortical inhibitory interneurons in vivo (Atencio and Schreiner, 2008; Wu et al., 2008). FS cells have short-duration intracellular waveforms and high-frequency, nonaccommodating spiking responses to current injection in vitro. They tend to be basket- or chandelier-type inhibitory neurons that stain positively for PV (Kawaguchi and Kubota, 1993, 1997; Wang et al., 2002a). Although narrow spikes are typical of PV+ inhibitory neurons, using extracellular waveforms to identify them in vivo may result in both type I and type II misclassification errors, for two reasons. First, although studies in wild-type animals support the general validity of extracellular spike duration as a proxy for intracellular duration, its reliability can vary depending on the size of the recorded neuron and its position relative to the electrode (Henze et al., 2000; González-Burgos et al., 2005; Gold et al., 2006). Second, even using intracellular spikes, the FS/PV+ relationship is not one-to-one: not all $\mathrm{PV}+$ cells have narrow spikes, nor do all narrow-spike cells express PV (Gray and McCormick, 1996; Cauli et al., 2000; Markram et al., 2004). In fact, PV is expressed in only approximately half of basket cells (Markram et al., 2004).

To test this relationship we compared the extracellular spike waveforms of our PV + and PV - cells (Fig. 1f). PV + cells indeed 
a
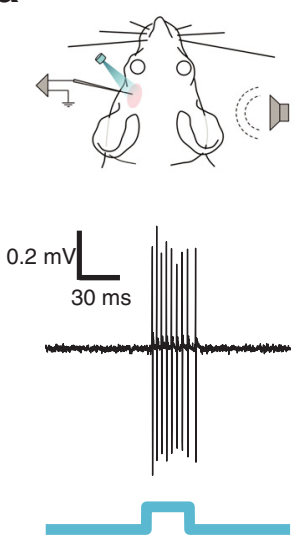

b

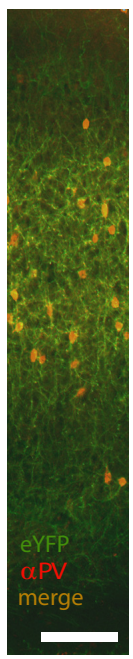

C

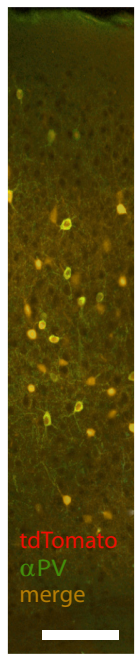

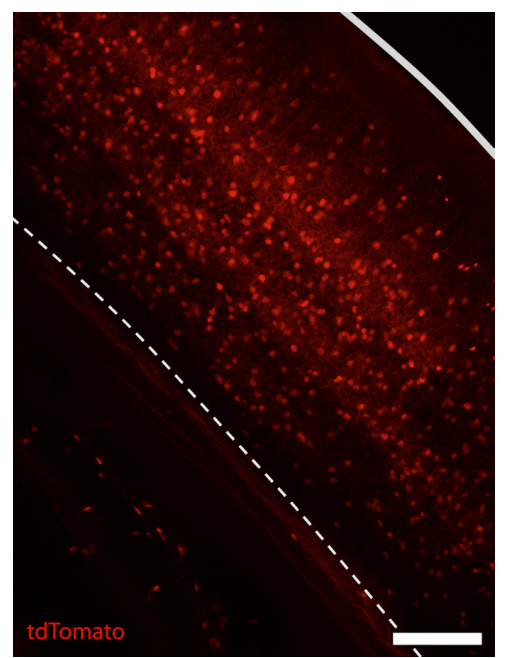

d

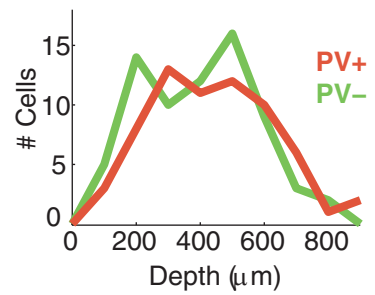

e
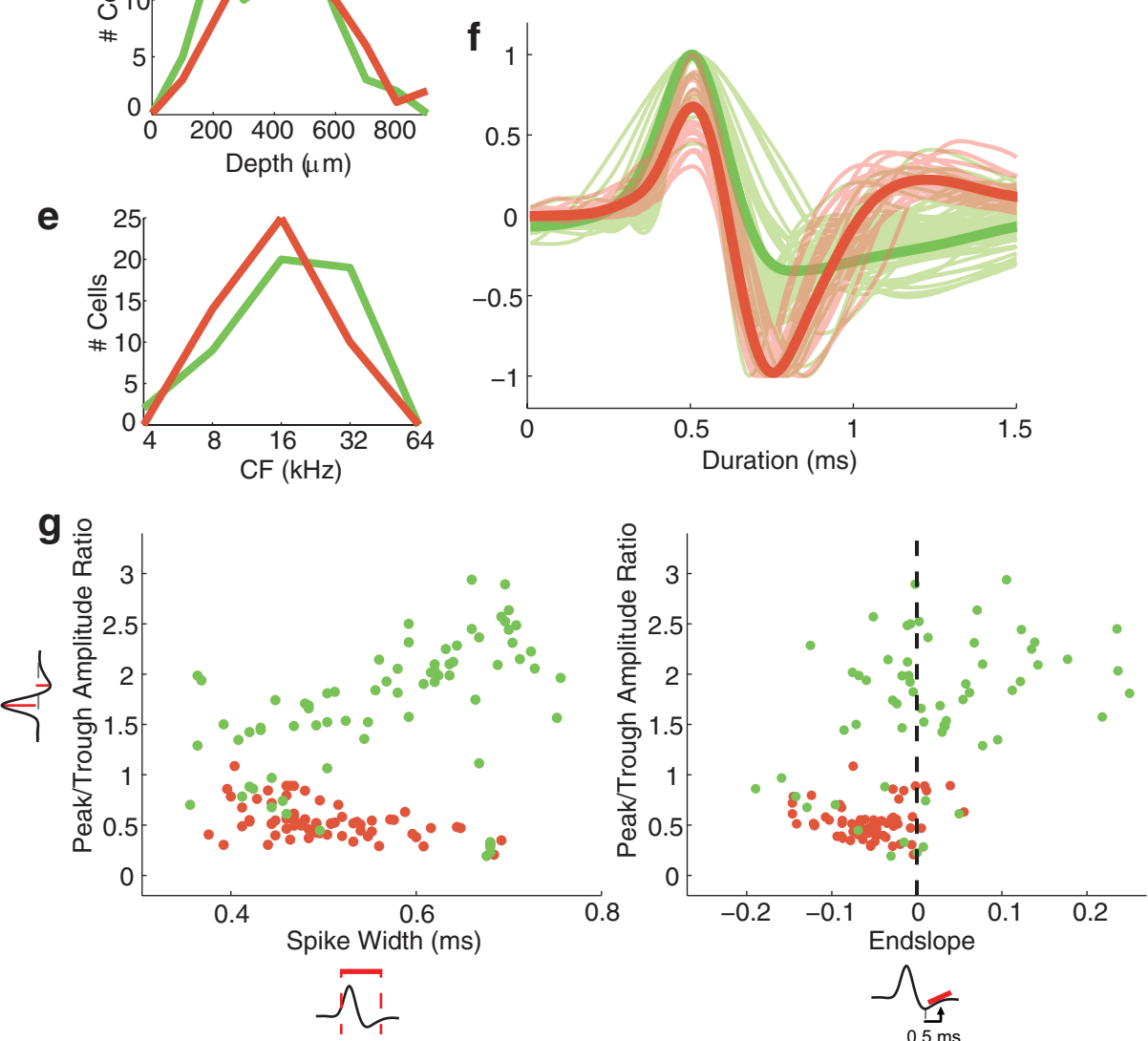

Figure 1. Identification of PV + interneurons. $\boldsymbol{a}$, We recorded from single neurons in the left auditory cortex of anesthetized ChR2-eYFP/PV-cre mice. PV + neurons were identified as neurons that showed reliable, short latency responses to pulses of blue light. For comparison, we collected a sample of PV - neurons in the same animals, which did not respond to light. Light was delivered by an LED positioned directly over the recording site. Expression pattern and specificity. $\boldsymbol{b}$, Immunostain for PV in ChR2-eYFP/PV-cre mice; section thickness $30 \mu \mathrm{m}$; scale bar, $100 \mu \mathrm{m}$. More than $97 \%$ of cells that stained positively for PV expressed eYFP ( $n=657$ cells in two mice, four sections total). c, PV-cre expression was visualized in a cross to a cytosolic tdTomato reporter line, where somata could be readily distinguished from processes. Left, Immunostain for PV in tdTomato/PV-cre mice; section thickness $30 \mu \mathrm{m}$; scale bar, $100 \mu \mathrm{m}$. More than $97 \%$ of cells expressing tdTomato stained positively for PV; $>96 \%$ of cells that stained positively for PV expressed tdTomato ( $n=638$ cells in one mouse, four sections). Right, Coronal section through auditory cortex; section thickness $200 \mu \mathrm{m}$, processed with Sca/e (Hama et al., 2011). Solid line indicates pial surface; dashed line indicates white matter boundary; scale bar, $200 \mu \mathrm{m}$. PV + cells were distributed throughout layers II-VI. $\boldsymbol{d}$, We sampled PV + (red, $n=68$ ) and PV - cells (green, $n=72$ ) from all cortical layers. $\boldsymbol{e}$, We sampled PV + and PV - cells across the tonotopic extent of A1.f, Average extracellular waveforms for individual PV + (red) and PV - neurons (green). Bold lines show group averages. Waveforms were normalized to peak or trough, whichever was larger. $\boldsymbol{g}$, Scatter plots show the distribution of spike waveform characteristics for PV + and PV - cells: spike width and endslope are plotted on the $x$-axes; peak/trough amplitude ratio is plotted on the $y$-axis. Spike width was measured from $20 \%$ of the peak to $20 \%$ of the trough. PV + cells tended to have narrow waveforms, low peak/trough amplitude ratios, and negative endslopes, although the two groups showed considerable overlap in all three measures. 
had narrower spikes than PV - cells (Fig. $1 g$; PV $+: 0.75 \pm 0.18$ $\mathrm{ms}, \mathrm{PV}-: 0.93 \pm 0.29 \mathrm{~ms}, p<0.01)$. They also differed from $\mathrm{PV}-$ cells on two other waveform measures frequently used to identify inhibitory interneurons: peak/trough ratio and endslope (Niell and Stryker, 2008; Runyan et al., 2010). PV+ cells had a significantly lower peak/trough amplitude ratio (Fig. 1g; PV+: $0.54 \pm 0.17, \mathrm{PV}-: 1.67 \pm 0.66, p<0.01)$ and a negative endslope (Fig. 1g; PV $+:-0.07 \pm 0.11, \mathrm{PV}-: 0.07 \pm 0.28, p<0.01$ ), which is the slope of the waveform measured $0.5 \mathrm{~ms}$ after the trough. Despite these marked differences at the population level, the two groups showed appreciable overlap for all waveform measures, consistent with other in vivo studies (Dykes et al., 1988; Nowak et al., 2003; Niell and Stryker, 2008; Liu et al., 2009). In our sample, 27/72 PV - neurons had narrow spikes (width $<0.8 \mathrm{~ms}$, see Materials and Methods), 29/72 had negative endslopes, and 17/72 had peak/trough ratios $<1$. Separating these neurons according to any one waveform measure could therefore result in a misclassification rate of up to $40 \%$, suggesting that extracellular waveforms are not reliable markers of $\mathrm{PV}+$ neurons. These results suggest that both PV+ and FS cells are heterogeneous populations that overlap but are not identical.

\section{Tuning width}

$\mathrm{PV}+$ neurons in mouse visual cortex are more broadly tuned for orientation than PV - neurons. We wondered whether PV+ neurons in auditory cortex might similarly be more broadly tuned for frequency. We measured frequency tuning widths using iso-intensity tone arrays at $20 \mathrm{~dB}$ above threshold, and quantified tuning width using $\sigma$ of a Gaussian fit. We were able to obtain complete frequency tuning curves for 46/68 PV + neurons and for $46 / 72 \mathrm{PV}-$ neurons. Figure $2 a$ shows an example of a frequency tuning curve for a well tuned $\mathrm{PV}+$ neuron, with the Gaussian fit in blue. This neuron had classic "V-shaped" frequency-intensity tuning (Fig. 2b,c) and a tuning width of 0.56 octaves (Fig. $2 a$ ). The frequency tuning curve was well fit by a Gaussian $\left(R^{2}=0.81\right)$, confirming that $\sigma$ was a reasonable estimate of tuning width. However, not all neurons were so well tuned. Figure $2 d$ shows an example of a frequency tuning curve for a PV+ neuron that was essentially "untuned". This neuron had disordered frequency-intensity tuning (Fig. 2e) but was nevertheless responsive to sounds: Figure $2 d$, inset shows a brisk tone-evoked response, comparable to that of the tuned neuron in Figure $2 a$, inset. Like the tuned example cell, its firing rate increased monotonically with sound level (Fig. $2 c, f$ ). For this untuned but sound-responsive neuron, a Gaussian fit provided a poor estimate of tuning width (Fig. $2 d ; R^{2}=0.04$ ); indeed, the notion of tuning width seems inappropriate to describe such a neuron, and we therefore categorized this neuron as untuned (UT). We categorized neurons as either tuned or untuned based on the goodness of a Gaussian fit, using an arbitrary criterion of $R^{2}=0.2$ (varying this value by \pm 0.2 did not affect our result, see Materials and Methods). By this criterion, 6/46 PV+ and 6/46 $\mathrm{PV}-$ cells were untuned and we excluded these cells from our tuning width analysis. The prevalence of untuned neurons was identical in our PV + and PV - samples, and they showed no difference from tuned neurons in terms of spike width, spontaneous firing rate, or cortical depth. Of the tuned cells, we excluded 9/40 PV + cells and 6/40 PV - cells with best frequencies outside the frequency range of our speaker, because this truncated the upper flank of the tuning curve and we could not confidently measure their tuning width. This resulted in a sample of $31 \mathrm{PV}+$ and $34 \mathrm{PV}-$ neurons for which we could estimate tuning width with high confidence.
The tuning widths of these 65 cells ranged from extremely tightly tuned ( $\sigma=0.17$ octaves) to broadly tuned ( $\sigma=2.3$ octaves; Fig. $2 g, h)$. Although PV + cells were slightly more broadly tuned on average, the mean tuning widths of PV + and PVneurons were not significantly different $(\mathrm{PV}+: 0.84 \pm 0.52 \mathrm{oc}-$ taves, PV-: $0.62 \pm 0.51$ octaves, $p=0.06)$. The tuning width distributions were largely overlapping (Fig. $2 h$ ), although we noted that there were fewer "very tightly" tuned PV + cells $(\sigma<$ 0.5 octaves, $9 / 31,29 \%)$ than PV - cells $(20 / 34,58 \% ; p<0.05$, Fisher's exact test); note the cluster of PV - cells between 200 and $400 \mu \mathrm{m}$ with a tuning width $\sigma<0.5$ octaves in Figure 2i. Nevertheless, the more sensitive Kolmogorov-Smirnov statistic confirmed that the distributions of $\mathrm{PV}+$ and $\mathrm{PV}-$ tuning widths were not significantly different $(p=0.08)$. There was no difference in depth between the PV + and PV - neurons included in the analysis (Fig. $2 i$; PV $+: 442 \pm 198 \mu \mathrm{m}, \mathrm{PV}-: 368 \pm 165 \mu \mathrm{m}$, $p>0.05)$. The best frequencies of all tuned PV + neurons fell within one half octave of the best frequency of their recording sites, as estimated from multiunit or local field potential tuning curves (mean difference: $0.0 \pm 0.1$ octaves), indicating that the tuning of PV + cells matched that of the local population.

Two earlier studies have characterized waveform-identified FS cells in cat and rat A1, focusing primarily on cells in layer IV (Atencio and Schreiner, 2008; Wu et al., 2008). Both found that FS cells were significantly more broadly tuned than RS cells. Indeed, when we separated our cells according to spike width, rather than expression-type, we found that narrow-spike cells (width $<0.8 \mathrm{~ms}, n=32$ ) were significantly more broadly tuned than broad-spike cells ( $n=33$; narrow-spike, FS: $0.87 \pm 0.57$ octaves; broad-spike, RS: $0.60 \pm 0.44$ octaves, $p=0.04$ ). Figure $2 j$ compares the tuning and spike widths of PV + and PV - cells, with the spike width cutoff shown by the dashed line. Note the handful of well tuned PV + cells that fall into the RS category (red $\mathrm{x}$ 's) and the broadly tuned PV - cells that fall in the FS category (green x's).

\section{Spontaneous and evoked firing rate}

We compared the spontaneous and sound-evoked firing rates of $\mathrm{PV}+$ and $\mathrm{PV}-$ cells using responses to white noise at best intensity. Consistent with reports from mouse visual cortex (Liu et al., 2009; Atallah et al., 2012), PV + cells had twofold higher spontaneous (Fig. $3 a$; PV $+: 5.5 \pm 4.8 \mathrm{~Hz} n=57, \mathrm{PV}-: 2.0 \pm 2.5 \mathrm{~Hz} n=$ $49, p<0.01$ ) and evoked firing rates (Fig. $3 a ; \mathrm{PV}+: 30.3 \pm 26.6$ $\mathrm{Hz}(2.4 \pm 2.1$ spikes/stimulus $), \mathrm{PV}-: 14.5 \pm 11.4 \mathrm{~Hz}(1.1 \pm 0.9$ spikes/stimulus), $p<0.01)$. The trial-to-trial variability of evoked responses was also significantly higher for PV + neurons (trial-averaged SD of WN-evoked firing rates, $\mathrm{PV}+: 15.28 \pm 8.29$ $\mathrm{Hz}, \mathrm{PV}-: 8.26 \pm 5.82 \mathrm{~Hz}, p<0.001$; this was also true for CFevoked firing rates, $\mathrm{PV}+: 16.40 \pm 11.26 \mathrm{~Hz} n=48, \mathrm{PV}-: 7.59 \pm$ $4.54 \mathrm{~Hz} n=39, p<0.001)$.

\section{Response latency}

$\mathrm{PV}+$ cells had shorter response latencies than PV - cells (Fig. $3 b, c ; \mathrm{PV}+: 17.9 \pm 5.9 \mathrm{~ms}, n=31, \mathrm{PV}-: 29.1 \pm 10.9 \mathrm{~ms}, n=34$, $p<0.001$ ), as measured at best frequency, $20 \mathrm{~dB}$ above threshold. This is consistent with a previous study of FS cells in auditory cortex (Atencio and Schreiner, 2008). Interestingly, response latencies to white noise were not significantly different $(20 \mathrm{~dB}$ above white noise threshold, PV $+: 22.0 \pm 9.6 \mathrm{~ms}, n=57$; PV-: $25.9 \pm 13.7 \mathrm{~ms}, n=49, p>0.05$ ), possibly due to the high variability in $\mathrm{PV}-$ response latencies for white noise. We confirmed these results using an alternative latency estimation method. Consistent with the original analysis, the modal first- 

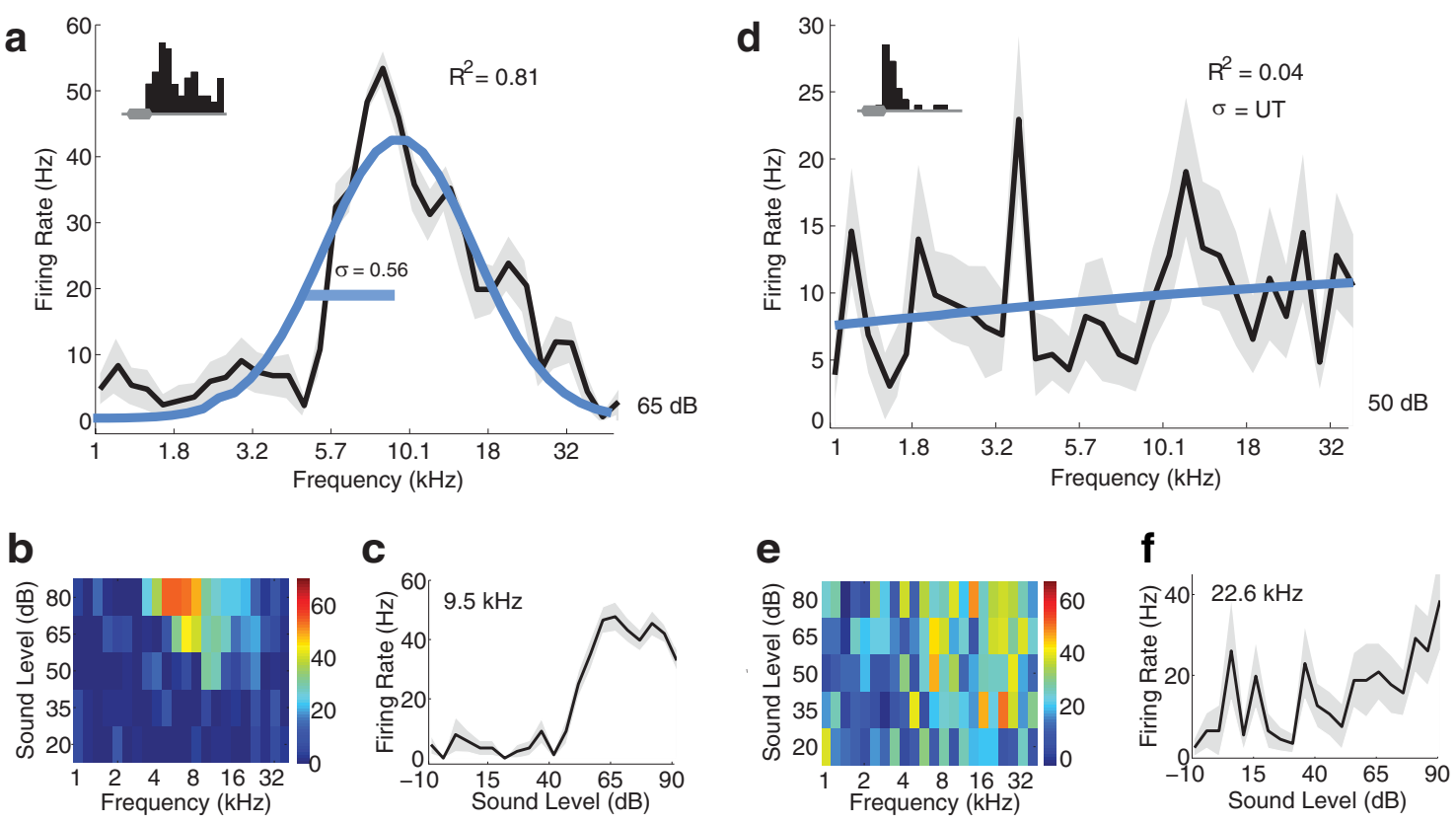
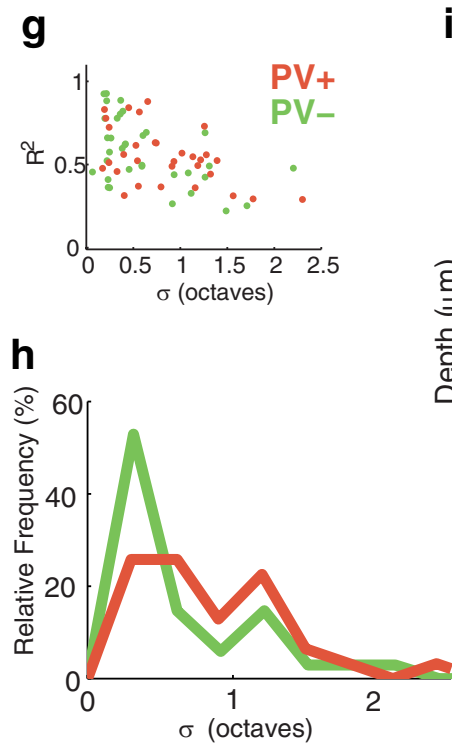

i

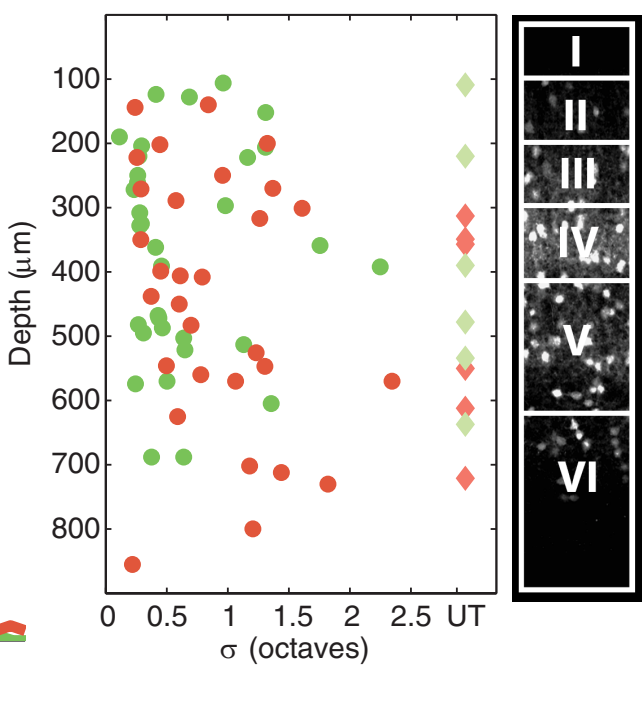

Figure 2. Frequency tuning width. We measured frequency tuning using iso-intensity tuning curves $20 \mathrm{~dB}$ above sound threshold. We quantified tuning bandwidth as $\sigma$ of a Gaussian fit. Examples of a tuned PV + cell $(\boldsymbol{a}-\boldsymbol{c})$ and an untuned PV + cell $(\boldsymbol{d}-\boldsymbol{f}) . \boldsymbol{a}, \boldsymbol{d}$, Frequency tuning curves for two example neurons with the Gaussian fits in blue, SEM in gray. Both cells were sound responsive (insets). The neuron in $\boldsymbol{a}$ was well fit by a Gaussian $\left(R^{2}=0.81\right)$, confirming that $\sigma$ was a reasonable estimate of tuning width. The neuron in $\boldsymbol{b}$ was poorly fit by a Gaussian $\left(R^{2}=0.04\right)$ and was therefore categorized as untuned (UT). $\boldsymbol{b}, \boldsymbol{e}$, Coarse frequency-intensity tuning curves show the classic "V-shaped" tuning of the first neuron and the disordered tuning of the second. $\boldsymbol{c}, \boldsymbol{f}$, We used a high-resolution rate-level function at each cell's CF to determine pure tone thresholds, which were then used to select the appropriate intensity for frequency tuning curves. $\boldsymbol{g}$, Goodness-of-fit measure $\left(R^{2}\right)$ versus tuning width $(\sigma)$ for cells included in the tuning width analysis (PV + red, $n=31 ; P V-$ green, $n=34$ ). PV + cells were not significantly more broadly tuned than PV - cells. Cells with $R^{2}<0.2$ were categorized as untuned and not included. $\boldsymbol{h}$, Distribution of tuning widths for PV + and PV - cells. PV + cells could be narrowly tuned, but fewer PV + cells (9/31, 29\%) were very narrowly tuned ( $\sigma<0.5$ octaves), compared with PV - cells (20/34,58\%). $i$, Left, Scatter plot of tuning width versus depth for tuned cells (circles) and untuned cells (diamonds). Right, layer boundaries (Anderson et al., 2009) and distribution of PV + neurons (visualized by tdTomato as in Fig. 1c). $\boldsymbol{j}$, Tuning width versus spike width. When categorized according to spike width rather than expression-type, thin-spike cells (width $<0.8 \mathrm{~ms}$, points falling below the dotted line) were significantly more broadly tuned than broad-spike cells. This difference is due to several well tuned PV + cells that fall into the RS category (red x's) and several broadly tuned PV - cells that fall in the FS category (green x's).

spike latencies of PV+ cells were significantly shorter for tones at CF, but not for WN.

\section{Response gain and monotonicity}

Synaptic inhibition shapes how auditory neurons respond to increasing sound levels (Wu et al., 2006; Tan et al., 2007), but the involvement of $\mathrm{PV}+$ neurons in these processes is not known. To investigate possible differences in the response gain and intensity tuning of the $\mathrm{PV}+$ and $\mathrm{PV}-$ populations, we compared their sound-evoked firing rates across a range of sound levels (a ratelevel function). We fit rate-level functions with a two-tailed split Gaussian (Watkins and Barbour, 2011), which fit both monotonic neurons (Fig. 4a) and nonmonotonic, or "intensity-tuned", neurons (Fig. $4 b$ ).

We first looked for differences in response gain, which we defined as the relationship between sound level (input) and the cell's spiking response (output). We measured response gain as the average slope of the rate-level function; that is, by dividing the 

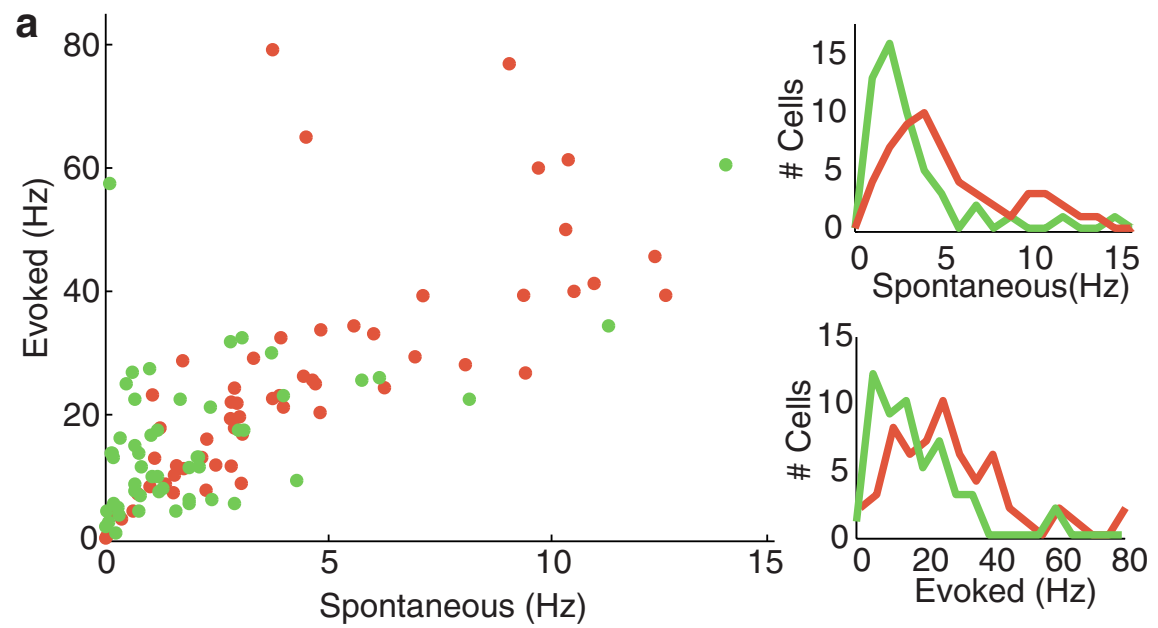

b

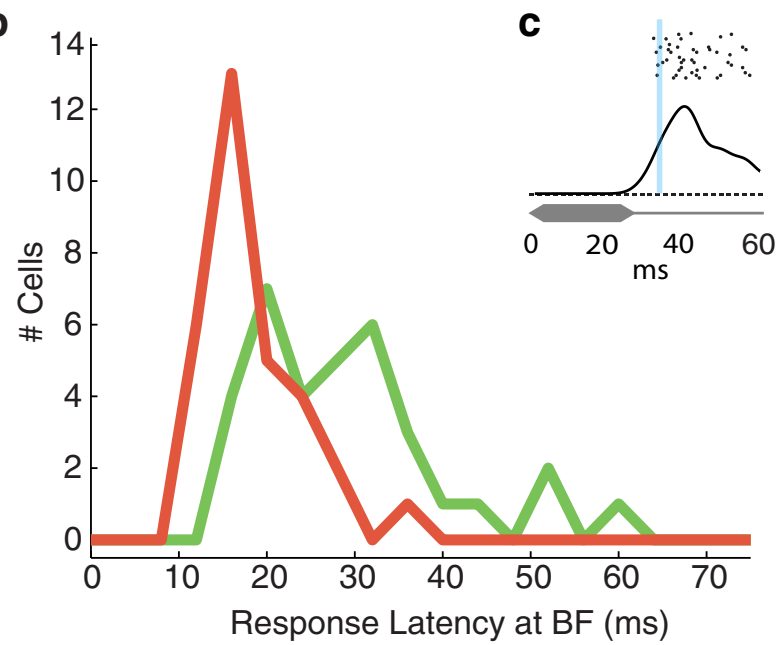

Figure 3. Firing rates and response latency. $\boldsymbol{a}$, Spontaneous and evoked firing rates for PV $+($ red, $n=57)$ and PV- (green, $n=$ 49) cells. Distributions are shown separately on the right. Evoked firing rates were measured using $25 \mathrm{~ms}$ white noise bursts at best intensity. Evoked rates were computed from the spike count in the $0-80 \mathrm{~ms}$ period following stimulus onset, averaged across trials. Spontaneous firing rates were computed the same way, but for the $-80-0 \mathrm{~ms}$ window preceding stimulus onset. Response latency. $\boldsymbol{b}$, Histogram of response latencies at best frequency, $20 \mathrm{~dB}$ above threshold ( $n=31 \mathrm{PV}+, 34 \mathrm{PV}-$ cells). $\boldsymbol{c}$, Computing response latency. Spike times were accumulated for repeated presentations of the stimulus and smoothed by Gaussian convolution (black trace). Response latency (blue line) was estimated as the time at which the smoothed spike train surpassed $50 \%$ of the poststimulus maximum, above spontaneous baseline. This process was repeated using spike times from 10 of 20 presentations, randomly drawn. Latency was taken as the mean of the distribution of latency estimates for 1000 subsamples.

dynamic range in firing rate (Fig. $4 a, \Delta \mathrm{FR}$ ) by the dynamic range in sound level (Fig. $4 a, \Delta \mathrm{dB}$ ), measured from response threshold to saturation. This initial measure of gain was not different between $\mathrm{PV}+$ and $\mathrm{PV}-$ neurons at $\mathrm{CF}(\mathrm{PV}+: 1.16 \pm 1.67, n=48$, PV-:1.03 $\pm 1.59, n=38, p>0.05)$. However, this measure of gain is strongly affected by evoked firing rate, which was significantly higher in $\mathrm{PV}+$ neurons (Fig. 3a). Indeed, PV + neurons had a significantly greater dynamic range in firing rate (Fig. $4 c, \Delta$ FR; PV+: $21.1 \pm 18.3 \mathrm{~Hz}, \mathrm{PV}-: 8.6 \pm 6.5 \mathrm{~Hz}, p<0.01)$. We therefore normalized rate-level functions to control for the higher firing rates in $\mathrm{PV}+$ neurons.

When we normalized CF rate-level functions for maximal evoked firing rate, $\mathrm{PV}+$ neurons had a significantly shallower gain than PV - neurons (Fig. $4 d$, top; PV $+: 0.04 \pm 0.05$, PV-: $0.15 \pm 0.24, p<0.01)$. In other words, their responses increased over a greater range of sound intensities (Fig. 4e, top, $\Delta \mathrm{dB}$; $\mathrm{PV}+$ : $32 \pm 18 \mathrm{~dB}, \mathrm{PV}-: 19 \pm 15 \mathrm{~dB}, p<0.01)$. This was not a consequence of lower sound thresholds, since threshold levels for pure tones were no different between $\mathrm{PV}+$ and $\mathrm{PV}-$ neurons (Fig. 4f; PV $+: 26 \pm 19 \mathrm{~dB}$, $P V-: 28 \pm 19 \mathrm{~dB}, p>0.05)$. This was also true when we separated cells according to spike width, which is inconsistent with a previous study of FS cells in rat $\mathrm{A} 1$ (Wu et al., 2008).

We wondered whether the shallower gain of $\mathrm{PV}+$ neurons, corresponding to greater sound level dynamic range, could be explained by their degree of intensity tuning. This idea is illustrated in Figure $4 a, b$. The dynamic range $(\Delta \mathrm{dB})$ for the monotonic neuron in Figure $4 a$ is much greater than that for the nonmonotonic neuron in Figure $4 b$. This occurs because the nonmonotonic neuron reaches its best intensity (and therefore maximal firing rate) at a lower intensity than the monotonic neuron, which continues to increase its firing rate across a greater range of sound levels. To evaluate the strength of intensity tuning for the two groups, we computed a monotonicity index (MI; see Materials and Methods). MI ranges from 0 to 1 , where 1 indicates no intensity tuning (monotonic) and 0 indicates strong intensity tuning (nonmonotonic). Indeed, for pure tone stimuli at $\mathrm{CF}$, mean MI was significantly higher for $\mathrm{PV}+$ cells (Fig. $4 g$, top; PV $+: 0.76 \pm 0.22, \mathrm{PV}-$ : $0.55 \pm 0.28, p<0.01$ ), indicating that $\mathrm{PV}+$ neurons are more monotonic than PV - neurons. Similarly, when we categorized neurons as either monotonic or nonmonotonic using a criterion of $\mathrm{MI}=$ 0.5 (Sutter and Schreiner, 1995; de la Rocha et al., 2008; Watkins and Barbour, 2011), only $14 \%$ of PV + cells (7/48) were nonmonotonic, compared with $55 \%$ of PV - cells $(21 / 38 ; p<0.01$, Fisher's exact test). Moreover, $\Delta \mathrm{dB}$ was correlated with MI $(r=0.377, p<0.01)$, suggesting that the greater monotonicity of $\mathrm{PV}+$ neurons is responsible for their increased dynamic range in sound level, and thus their comparatively shallow response gain.

Interestingly, this conclusion is supported by a different pattern of results for responses to white noise. When we used white noise to measure rate-level functions, we found that $\mathrm{PV}+$ and $\mathrm{PV}-$ neurons were not significantly different in terms of monotonicity (Fig. $4 g$, bottom; PV $+: 0.77 \pm 0.21, n=57, \mathrm{PV}-: 0.67 \pm$ $0.28, n=49, p>0.05)$. This was not due to a difference in the intensity tuning of $\mathrm{PV}+$ responses to white noise or CF tones, which were similarly monotonic (MI, CF: $0.76 \pm 0.22$ vs WN: $0.77 \pm 0.21, p>0.05)$. Rather, PV - cells were more monotonic for white noise than for CF tones (MI, CF: $0.55 \pm 0.28$ vs WN: $0.67 \pm 0.28, p<0.05$ ), as has been described previously in cat A1 (Phillips et al., 1985) and is consistent with models of auditory cortical circuitry (Levy and Reyes, 2011). Because PV+ and PVneurons had no difference in monotonicity for white noise, there was no difference in the dynamic range for sound level between $\mathrm{PV}+$ and $\mathrm{PV}-$ neurons (Fig. 4e, bottom; PV+: $23 \pm 16 \mathrm{~dB}$, 
a

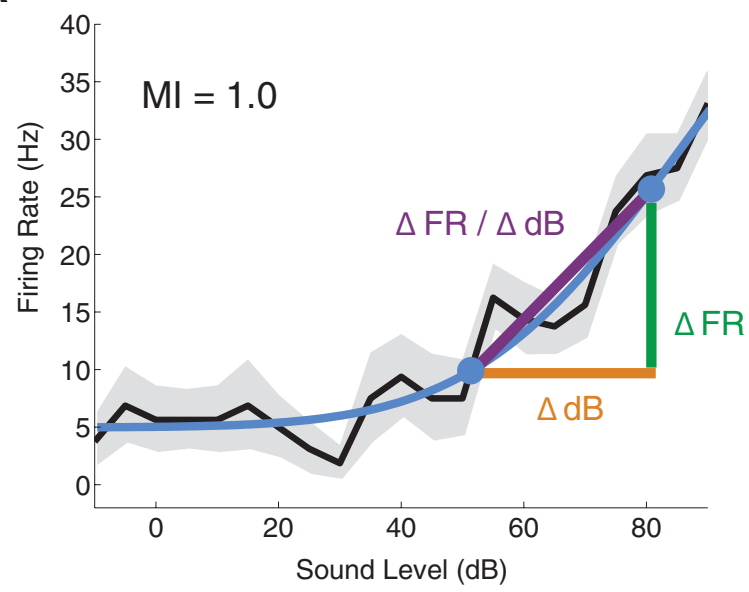

C

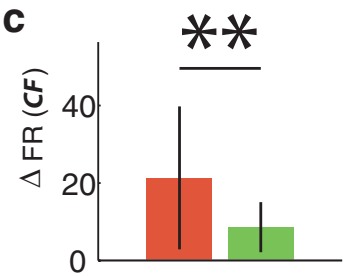

f

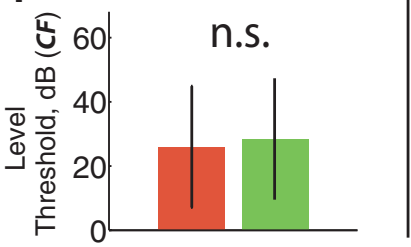

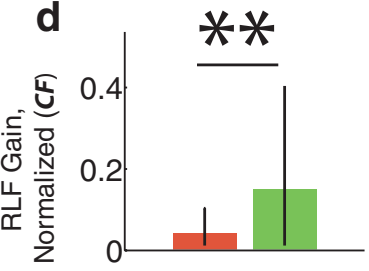

e
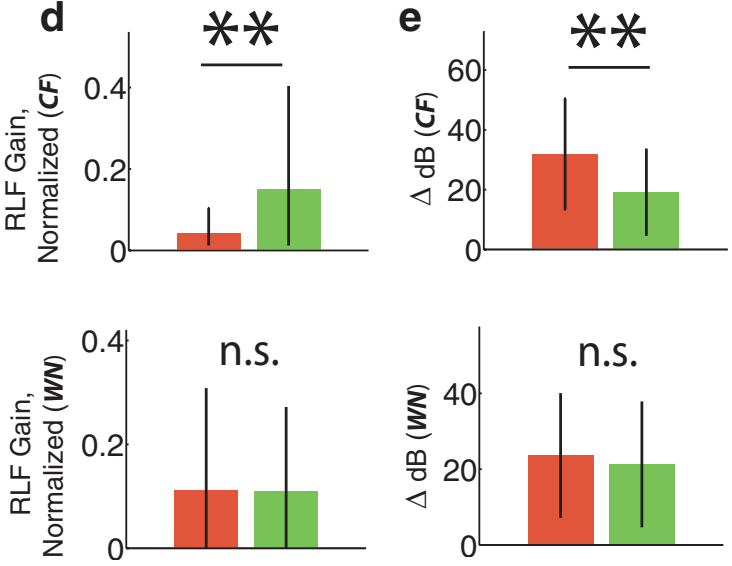

b

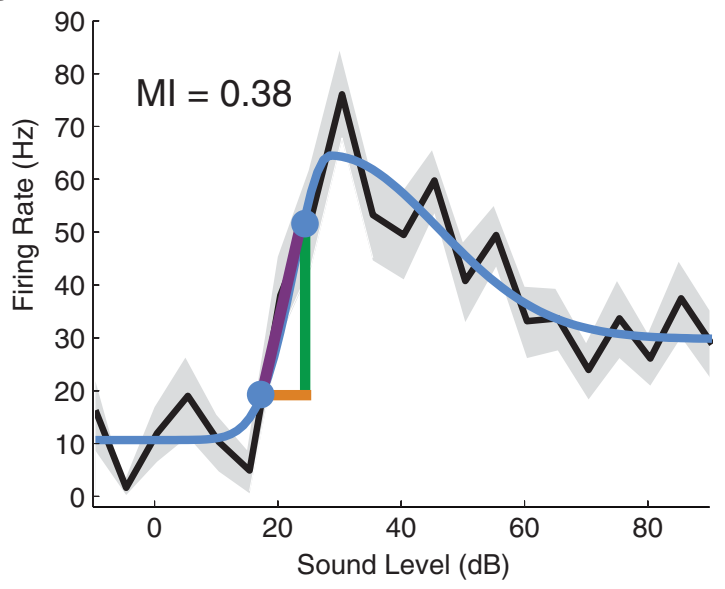

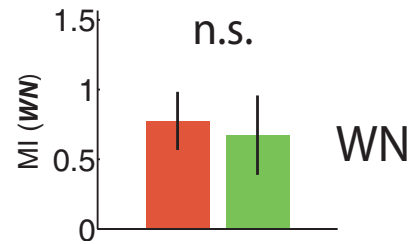

Figure 4. RLFs. Example rate-level functions for (a) a monotonic, and (b) a nonmonotonic PV + neuron, for responses to tones at CF. Best intensity was $90 \mathrm{~dB}$ in $\boldsymbol{a}$ and $30 \mathrm{~dB}$ in $\boldsymbol{b}$. SEM is shown in gray. Fitted curves, shown in blue, were generated with a six-parameter split Gaussian model (Watkins and Barbour, 2011). Threshold (20\% of maximum) and saturation points (80\% of maximum) are indicated by filled circles on the curves. Firing rate dynamic range $(\Delta \mathrm{FR})$ and sound level dynamic range $(\Delta \mathrm{dB})$ are indicated by the green and orange bars. The slope of the rate-level function $(\Delta \mathrm{FR} / \Delta \mathrm{dB})$ is shown in purple. $c, P V+$ neurons had a greater dynamic range in firing rate (also true for white noise; data not shown). Error bars are SD. $f$, Tone intensity thresholds for PV + and PV - neurons were not significantly different. $\boldsymbol{d}, \boldsymbol{e}, \boldsymbol{g}$, Top, Compares rate-level function parameters for PV + and PV - cells at CF; bottom, compares the same parameters for white noise. $\boldsymbol{d}$, RLFs normalized to maximal evoked firing rate. For $C F$ tones, PV + neurons had a shallower gain than PV - neurons ( $\Delta \mathrm{FR} / \Delta \mathrm{dB})$. $\boldsymbol{e}, \mathrm{PV}+$ neurons had greater sound level dynamic range for $C F$ tones. $\boldsymbol{g}, \mathrm{PV}+$ neurons had more monotonic (F rate-level functions (monotonicity index, MI). White noise rate-level functions (bottom) showed a different pattern of results: PV + and PV neurons were not significantly different in terms of response gain $(\boldsymbol{d}$, bottom), sound level dynamic range ( $\boldsymbol{e}$, bottom), or monotonicity $(\boldsymbol{g}$, bottom).

$\mathrm{PV}-: 21 \pm 17 \mathrm{~dB}, p>0.05)$, and also no difference in response gain (Fig. $4 d$, bottom; PV $+: 0.11 \pm 0.19, \mathrm{PV}-: 0.11 \pm 0.16, p>$ $0.05)$ for white noise. This suggests that the significantly shallower gain of $\mathrm{PV}+$ responses to $\mathrm{CF}$ tones can be accounted for by their greater monotonicity, given that these differences vanished when we used stimuli for which PV- and PV+ neurons were similarly monotonic.

\section{Layer differences}

To test whether these differences between $\mathrm{PV}+$ and PV - neurons depended on cortical layer, we assigned cells to the supragranular (L1-3, <300 $\mu \mathrm{m}$ ), granular (L4 and lower L3, 300-500 $\mu \mathrm{m}$ ), and subgranular layers (L5-6, >500 $\mu \mathrm{m}$; Anderson et al., 2009). We then compared the properties of PV + and PV - cells in each of the three layer groups, separately. The differences reported above for $\mathrm{PV}+$ and $\mathrm{PV}-$ cells across all layers were also true for PV + and PV - cells within in these groups (Wilcoxon rank sum test, significance level $=0.05$ ). Varying the layer boundaries $\pm 50 \mu \mathrm{m}$ did not change this result. Moreover, PV+ cells in different layer groups did not differ significantly from one another for any of these measures ( $p>0.05$, one-way ANOVA).

\section{Discussion}

Understanding the receptive field properties of different inhibitory cell types is critical to unraveling their specific roles in sound processing. Here we characterized the tuning properties of PV+ interneurons in mouse auditory cortex and compared them to those of $\mathrm{PV}-$ neurons. We found that the receptive field properties of PV+ and PV - neurons were largely similar. PV + neurons did differ from $\mathrm{PV}$ - neurons in a few respects, suggesting computational roles for $\mathrm{PV}+$-mediated inhibition in shaping intensity tuning, enhancing temporal precision, and providing dynamic gain control.

\section{$\mathrm{PV}+$ tuning width}

Our finding that the tuning widths of PV+ and PV- neurons were not significantly different is consistent with the idea that $\mathrm{PV}+$ cells nonselectively "pool" input from local excitatory neurons (Kerlin et al., 2010; Hofer et al., 2011). This idea is based on 
the observation that $\mathrm{PV}+$ interneurons receive dense input from nearby excitatory cells (Thomson and Lamy, 2007). In mouse auditory cortex, the pyramidal-to-PV + connection probability is distance-dependent, dropping to zero when somata are several hundred micrometers apart. Within that radius, connection probability is at least twofold higher than that between pyramidal cells (Oswald and Reyes, 2008; Levy and Reyes, 2012), which are driven by sparser, nonrandom connections (Song et al., 2005; Yoshimura et al., 2005; Barbour and Callaway, 2008; Hromádka et al., 2008). Because PV + neurons densely sample a small radius, their tuning is expected to reflect feature organization in local networks: in orientation columns in cat $\mathrm{V} 1$ and vibrissa barrels in rodent S1, PV + cells will sample inputs with homogeneous tuning, and thus themselves will be well tuned (Simons, 1978; Hirsch et al., 2003; Cardin et al., 2007; Nowak et al., 2008). In contrast, $\mathrm{PV}+$ neurons are found to be poorly tuned where cells with different stimulus preferences are organized in a salt-and-pepper fashion, as in mouse V1, which lacks orientation columns (Kerlin et al., 2010; Hofer et al., 2011; Zariwala et al., 2011).

Because mouse auditory cortex is tonotopically organized, the local pooling hypothesis predicts that PV + cells, like PV - cells, will be well tuned to an area's preferred frequency. Consistent with this, we found that the frequency tuning widths of $\mathrm{PV}+$ and $\mathrm{PV}-$ cells were not significantly different. Moreover, the frequency tuning of PV + cells matched that of the local population, as measured by the local field potential. Although tonotopy is present on a large scale in mouse $\mathrm{A} 1$, the tuning of neighboring neurons can be diverse at a fine scale (Bandyopadhyay et al., 2010; Rothschild et al., 2010). Consequently, unbiased local pooling would be unlikely to produce very narrowly tuned cells. Indeed, although the tuning width distributions were largely overlapping, there were comparatively few very tightly tuned PV + cells in our sample $(\sigma<0.5$ octaves, Fig. $2 i)$. We note that well tuned PV+ neurons are also consistent with selective connectivity rather than unbiased pooling, because narrow tuning could follow from either scheme. However, this would represent a different connectivity rule than is found in other cortical areas.

\section{Possible roles of $\mathrm{PV}+$-mediated inhibition Sharpening of frequency tuning}

$\mathrm{GABA}_{\mathrm{A}}$ blockade broadens spike tuning in auditory cortex (Wang et al., 2000; Chang et al., 2005; but see Kurt et al., 2006). This observation led to a model in which frequency tuning is substantially sharpened by lateral inhibition. More recently, voltage-clamp studies have shown that excitation and inhibition are instead cotuned for frequency and approximately fixed in their relative proportions (Wehr and Zador, 2003; Zhang et al., 2003; Tan et al., 2004; for review see Oswald et al., 2006). In the cotuning model, inhibition moderately sharpens spike tuning through a thresholding or "iceberg" mechanism, scaling down depolarization across the same range of frequencies as excitation. Cotuning of inhibition would readily arise as a consequence of local, unbiased pooling by inhibitory neurons. It predicts similar frequency tuning for excitatory and inhibitory neurons, and is consistent with our finding that the tuning widths of $\mathrm{PV}+$ and PV - cells were not different.

Lateral inhibition models propose that inhibition sharpens spike tuning by specifically inhibiting responses to nonpreferred stimuli (Calford and Semple, 1995; Chen and Jen, 2000; Sutter and Loftus, 2003). This could be implemented by PV + neurons that are more broadly tuned than excitatory neurons (Wu et al., 2008), but our finding that PV + and PV - neurons have similar tuning widths is inconsistent with this model. Alternatively, lat- eral inhibition could be provided by well tuned PV + neurons that project farther laterally than excitatory projections do. These $\mathrm{PV}+$ neurons would have tuning complementary to that of their excitatory targets. This model would be consistent with our results for tuning width, but inconsistent with our finding that $\mathrm{PV}+$ tuning matches that of the local population, as well as with a recent study in mouse auditory cortex that found that the spatial spread of excitatory and inhibitory neuronal connectivity was the same (Levy and Reyes, 2012). Together, our results therefore favor a model of cotuning of PV + neurons, produced by unbiased local connectivity, in which PV+-mediated inhibition has only a moderate impact on frequency tuning. Nevertheless, lateral inhibition could still be implemented in auditory cortex in at least two ways. First, recent modeling studies have shown that a single network architecture (which is consistent with our results) can operate in either a cotuned or lateral inhibition configuration, depending on the strength and spatial profile of thalamic input (Levy and Reyes, 2011). Second, other inhibitory cell types could participate in classical lateral inhibition.

Cotuned inhibition can sharpen frequency tuning in at least two ways. In addition to producing a general iceberg effect, "approximately" balanced inhibition that drops off slightly more gradually than excitation within the core of the receptive field can also sharpen tuning (Wu et al., 2008). Both mechanisms moderately sharpen tuning; the first predicts that excitatory and inhibitory neurons will have similar tuning, the second predicts that inhibitory neurons will be slightly more broadly tuned. We observed similar tuning for PV+ and PV - cells, but slightly broader tuning for FS cells (Fig. 2j), suggesting the possibility that these two mechanisms may be implemented by distinct inhibitory networks.

\section{Refining intensity tuning}

In cortical neurons, intensity tuning can be enhanced or even created de novo by an excess of cortical inhibition at high intensities (Wu et al., 2006; Tan et al., 2007). In these cases, weak or moderate intensity tuning of excitatory input is enhanced by monotonically increasing inhibition. We found that PV+ neurons were highly monotonic for pure tones at their characteristic frequency compared with PV - neurons. This supports the idea that local inhibition shapes intensity tuning in auditory cortex, and that it is provided at least in part by $\mathrm{PV}+$ neurons.

\section{Temporal precision}

Auditory cortical neurons can respond to sound with remarkable temporal precision and reliability (DeWeese et al., 2003) that can mediate perceptual decisions (Yang et al., 2008). Synaptic inhibition enhances this temporal precision (Wehr and Zador, 2003), but which specific interneurons provide this inhibition remains unknown. We found that PV+ neurons had markedly faster response latencies than $\mathrm{PV}-$ neurons. These very short latencies suggest that $\mathrm{PV}+$ neurons participate in a feedforward inhibitory network that is rapidly activated by thalamocortical excitation, and likely underlies the sequence of early synaptic excitation and inhibition seen in whole-cell recordings from pyramidal neurons (Wehr and Zador, 2003). The rapid activation of PV + neurons may arise from faster membrane time constants (Cardin et al., 2007 ) in combination with potent thalamocortical synaptic drive (Swadlow, 2003), as has been shown for FS cells in V1 and S1, respectively. This suggests that the PV + network is well positioned to enhance the timing and reliability of pyramidal responses, as well as quench the spread of cortical excitation.

Is a role in providing rapid feedforward inhibition compatible with the local pooling hypothesis? PV + neurons could play both 
roles, perhaps sequentially. After providing an initial volley of feedforward inhibition, PV + neurons could then pool activity from the local cortical network and provide ongoing feedback inhibition. Both roles could be performed simultaneously for continuous acoustic streams.

\section{Gain modulation}

Dynamic gain control is a key computational role of inhibition. By targeting the same frequencies as excitation, PV + interneurons may be capable of dynamically regulating the output gain of pyramidal cells without disrupting their frequency selectivity. Gain can be rapidly modulated in response to context, history, or training (Polley et al., 2004, 2006; Scholl et al., 2008; Rabinowitz et al., 2011), although the mechanisms underlying this modulation are complex and poorly understood. In V1, local pooling by cortical inhibition has been proposed to provide gain control by divisive normalization (Heeger, 1993). PV + cells in particular are suspected to implement dynamic gain regulation, given their perisomatic-targeting tendencies (Isaacson and Scanziani, 2011; Fino et al., 2013). We found that PV + interneurons had comparatively shallower response gain, which would be well suited for gain control by divisive normalization. Indeed, recent studies in mouse V1 have shown that PV + cells modulate the gain of visually evoked responses in a linear fashion without fundamentally altering their tuning properties (Atallah et al., 2012; Wilson et al., 2012). It will be of great interest to know whether the optogenetic manipulation of PV + cells reveals a similar principle in auditory cortex.

The picture that emerges from these results is that the receptive field and electrophysiological properties of $\mathrm{PV}+$ neurons are as diverse as those of other auditory cortical neurons. This is likely due at least in part to the degree of specificity of the PV promoter, which expresses in more than one cell type, but may also arise from heterogeneity within cell types as well. The diversity of receptive field properties may simply reflect that of pyramidal neurons, as would be expected from local pooling. Alternatively, it may indicate that PV + cells participate in distinct cortical circuits that implement different computations. Using intersectional optogenetics to achieve better cell-type specificity than that provided by the PV promoter alone could provide a way to distinguish between these two scenarios.

\section{References}

Anderson LA, Christianson GB, Linden JF (2009) Mouse auditory cortex differs from visual and somatosensory cortices in the laminar distribution of cytochrome oxidase and acetylcholinesterase. Brain Res 1252:130-142. CrossRef Medline

Atallah BV, Bruns W, Carandini M, Scanziani M (2012) Parvalbuminexpressing interneurons linearly transform cortical responses to visual stimuli. Neuron 73:159-170. CrossRef Medline

Atencio CA, Schreiner CE (2008) Spectrotemporal processing differences between auditory cortical fast-spiking and regular-spiking neurons. J Neurosci 28:3897-3910. CrossRef Medline

Bandyopadhyay S, Shamma SA, Kanold PO (2010) Dichotomy of functional organization in the mouse auditory cortex. Nat Neurosci 13:361368. CrossRef Medline

Barbour DL, Callaway EM (2008) Excitatory local connections of superficial neurons in rat auditory cortex. J Neurosci 28:11174-11185. CrossRef Medline

Calford MB, Semple MN (1995) Monaural inhibition in cat auditory cortex. J Neurophysiol 73:1876-1891. Medline

Cardin JA, Palmer LA, Contreras D (2007) Stimulus feature selectivity in excitatory and inhibitory neurons in primary visual cortex. J Neurosci 27:10333-10344. CrossRef Medline

Cauli B, Porter JT, Tsuzuki K, Lambolez B, Rossier J, Quenet B, Audinat E (2000) Classification of fusiform neocortical interneurons based on unsupervised clustering. Proc Natl Acad Sci U S A 97:6144-6149. CrossRef Medline
Chang EF, Bao S, Imaizumi K, Schreiner CE, Merzenich MM (2005) Development of spectral and temporal response selectivity in the auditory cortex. Proc Natl Acad Sci U S A 102:16460-16465. CrossRef Medline

Chen QC, Jen PH (2000) Bicuculline application affects discharge patterns, rate-intensity functions, and frequency tuning characteristics of bat auditory cortical neurons. Hear Res 150:161-174. CrossRef Medline

Cruikshank SJ, Killackey HP, Metherate R (2001) Parvalbumin and calbindin are differentially distributed within primary and secondary subregions of the mouse auditory forebrain. Neuroscience 105:553-569. CrossRef Medline

de la Rocha J, Marchetti C, Schiff M, Reyes AD (2008) Linking the response properties of cells in auditory cortex with network architecture: cotuning versus lateral inhibition. J Neurosci 28:9151-9163. CrossRef Medline

DeFelipe J (1997) Types of neurons, synaptic connections and chemical characteristics of cells immunoreactive for calbindin-D28K, parvalbumin and calretinin in the neocortex. J Chem Neuroanat 14:1-19. CrossRef Medline

DeWeese MR, Wehr M, Zador AM (2003) Binary spiking in auditory cortex. J Neurosci 23:7940-7949. Medline

Dykes RW, Lamour Y, Diadori P, Landry P, Dutar P (1988) Somatosensory cortical neurons with an identifiable electrophysiological signature. Brain Res 441:45-58. Medline

Fino E, Packer AM, Yuste R (2013) The logic of inhibitory connectivity in the neocortex. Neuroscientist 19:228-237. CrossRef Medline

Gold C, Henze DA, Koch C, Buzáaki G (2006) On the origin of the extracellular action potential waveform: a modeling study. J Neurophysiol 95: 3113-3128. CrossRef Medline

González-Burgos G, Krimer LS, Povysheva NV, Barrionuevo G, Lewis DA (2005) Functional properties of fast spiking interneurons and their synaptic connections with pyramidal cells in primate dorsolateral prefrontal cortex. J Neurophysiol 93:942-953. CrossRef Medline

Gray CM, McCormick DA (1996) Chattering cells: superficial pyramidal neurons contributing to the generation of synchronous oscillations in the visual cortex. Science 274:109-113. CrossRef Medline

Guo W, Chambers AR, Darrow KN, Hancock KE, Shinn-Cunningham BG, Polley DB (2012) Robustness of cortical topography across fields, laminae, anesthetic states, and neurophysiological signal types. J Neurosci 32:9159-9172. CrossRef Medline

Hama H, Kurokawa H, Kawano H, Ando R, Shimogori T, Noda H, Fukami K, Sakaue-Sawano A, Miyawaki A (2011) Scale: a chemical approach for fluorescence imaging and reconstruction of transparent mouse brain. Nat Neurosci 14:1481-1488. CrossRef Medline

Heeger DJ (1993) Modeling simple-cell direction selectivity with normalized, half-squared, linear operators. J Neurophysiol 70:1885-1898. Medline

Henze DA, Borhegyi Z, Csicsvari J, Mamiya A, Harris KD, Buzsáki G (2000) Intracellular features predicted by extracellular recordings in the hippocampus in vivo. J Neurophysiol 84:390-400. Medline

Hippenmeyer S, Vrieseling E, Sigrist M, Portmann T, Laengle C, Ladle DR, Arber S (2005) A developmental switch in the response of DRG neurons to ETS transcription factor signaling. PLoS Biol 3:e159. CrossRef Medline

Hirsch JA, Martinez LM, Pillai C, Alonso JM, Wang Q, Sommer FT (2003) Functionally distinct inhibitory neurons at the first stage of visual cortical processing. Nat Neurosci 6:1300-1308. CrossRef Medline

Hofer SB, Ko H, Pichler B, Vogelstein J, Ros H, Zeng H, Lein E, Lesica NA, Mrsic-Flogel TD (2011) Differential connectivity and response dynamics of excitatory and inhibitory neurons in visual cortex. Nat Neurosci 14:1045-1052. CrossRef Medline

Hromádka T, Deweese MR, Zador AM (2008) Sparse representation of sounds in the unanesthetized auditory cortex. PLoS Biol 6:e16. CrossRef Medline

Isaacson JS, Scanziani M (2011) How inhibition shapes cortical activity. Neuron 72:231-243. CrossRef Medline

Ison JR, Allen PD, O’Neill WE (2007) Age-related hearing loss in C57BL/6J mice has both frequency-specific and nonfrequency-specific components that produce a hyperacusis-like exaggeration of the acoustic startle reflex. J Assoc Res Otolaryngol 8:539-550. CrossRef Medline

Kawaguchi Y, Kubota Y (1993) Correlation of physiological subgroupings of nonpyramidal cells with parvalbumin- and calbindinD28k-immunoreactive neurons in layer V of rat frontal cortex. J Neurophysiol 70:387-396. Medline Kawaguchi Y, Kubota Y (1997) GABAergic cell subtypes and their synaptic 
connections in rat frontal cortex. Cereb Cortex 7:476-486. CrossRef Medline

Kerlin AM, Andermann ML, Berezovskii VK, Reid RC (2010) Broadly tuned response properties of diverse inhibitory neuron subtypes in mouse visual cortex. Neuron 67:858-871. CrossRef Medline

Kuhlman SJ, Huang ZJ (2008) High-resolution labeling and functional manipulation of specific neuron types in mouse brain by Cre-activated viral gene expression. PLoS One 3:e2005. CrossRef Medline

Kuhlman SJ, Tring E, Trachtenberg JT (2011) Fast-spiking interneurons have an initial orientation bias that is lost with vision. Nat Neurosci 14: 1121-1123. CrossRef Medline

Kurt S, Crook JM, Ohl FW, Scheich H, Schulze H (2006) Differential effects of iontophoretic in vivo application of the GABA(A)-antagonists bicuculline and gabazine in sensory cortex. Hear Res 212:224-235. CrossRef Medline

Levy RB, Reyes AD (2011) Coexistence of lateral and co-tuned inhibitory configurations in cortical networks. PLoS Comput Biol 7:e1002161. CrossRef Medline

Levy RB, Reyes AD (2012) Spatial profile of excitatory and inhibitory synaptic connectivity in mouse primary auditory cortex. J Neurosci 32:56095619. CrossRef Medline

Lima SQ, Hromádka T, Znamenskiy P, Zador AM (2009) PINP: a new method of tagging neuronal populations for identification during in vivo electrophysiological recording. PLoS One 4:e6099. CrossRef Medline

Liu BH, Li P, Li YT, Sun YJ, Yanagawa Y, Obata K, Zhang LI, Tao HW (2009) Visual receptive field structure of cortical inhibitory neurons revealed by two-photon imaging guided recording. J Neurosci 29:10520-10532. CrossRef Medline

Ma WP, Liu BH, Li YT, Huang ZJ, Zhang LI, Tao HW (2010) Visual representations by cortical somatostatin inhibitory neurons: selective but with weak and delayed responses. J Neurosci 30:14371-14379. CrossRef Medline

Madisen L et al. (2012) A toolbox of Cre-dependent optogenetic transgenic mice for light-induced activation and silencing. Nat Neurosci 15:793-802. CrossRef Medline

Madisen L, Zwingman TA, Sunkin SM, Oh SW, Zariwala HA, Gu H, Ng LL, Palmiter RD, Hawrylycz MJ, Jones AR, Lein ES, Zeng H (2010) A robust and high-throughput Cre reporting and characterization system for the whole mouse brain. Nat Neurosci 13:133-140. CrossRef Medline

Markram H, Toledo-Rodriguez M, Wang Y, Gupta A, Silberberg G, Wu C (2004) Interneurons of the neocortical inhibitory system. Nat Rev Neurosci 5:793-807. CrossRef Medline

Meyer HS, Schwarz D, Wimmer VC, Schmitt AC, Kerr JN, Sakmann B, Helmstaedter M (2011) Inhibitory interneurons in a cortical column form hot zones of inhibition in layers 2 and 5A. Proc Natl Acad Sci U S A 108:16807-16812. CrossRef Medline

Niell CM, Stryker MP (2008) Highly selective receptive fields in mouse visual cortex. J Neurosci 28:7520-7536. CrossRef Medline

Nowak LG, Azouz R, Sanchez-Vives MV, Gray CM, McCormick DA (2003) Electrophysiological classes of cat primary visual cortical neurons in vivo as revealed by quantitative analyses. J Neurophysiol 89:1541-1566. CrossRef Medline

Nowak LG, Sanchez-Vives MV, McCormick DA (2008) Lack of orientation and direction selectivity in a subgroup of fast-spiking inhibitory interneurons: cellular and synaptic mechanisms and comparison with other electrophysiological cell types. Cereb Cortex 18:1058-1078. CrossRef Medline

Oswald AM, Reyes AD (2008) Maturation of intrinsic and synaptic properties of layer $2 / 3$ pyramidal neurons in mouse auditory cortex. J Neurophysiol 99:2998-3008. CrossRef Medline

Oswald AM, Schiff ML, Reyes AD (2006) Synaptic mechanisms underlying auditory processing. Curr Opin Neurobiol 16:371-376. CrossRef Medline

Phillips DP, Orman SS, Musicant AD, Wilson GF (1985) Neurons in the cat's primary auditory cortex distinguished by their responses to tones and wide-spectrum noise. Hear Res 18:73-86. CrossRef Medline

Polley DB, Heiser MA, Blake DT, Schreiner CE, Merzenich MM (2004) Associative learning shapes the neural code for stimulus magnitude in primary auditory cortex. Proc Natl Acad Sci U S A 101:16351-16356. CrossRef Medline

Polley DB, Steinberg EE, Merzenich MM (2006) Perceptual learning directs auditory cortical map reorganization through top-down influences. J Neurosci 26:4970-4982. CrossRef Medline
Rabinowitz NC, Willmore BD, Schnupp JW, King AJ (2011) Contrast gain control in auditory cortex. Neuron 70:1178-1191. CrossRef Medline

Rothschild G, Nelken I, Mizrahi A (2010) Functional organization and population dynamics in the mouse primary auditory cortex. Nat Neurosci 13:353-360. CrossRef Medline

Runyan CA, Schummers J, Van Wart A, Kuhlman SJ, Wilson NR, Huang ZJ, Sur M (2010) Response features of parvalbumin-expressing interneurons suggest precise roles for subtypes of inhibition in visual cortex. Neuron 67:847-857. CrossRef Medline

Scholl B, Gao X, Wehr M (2008) Level dependence of contextual modulation in auditory cortex. J Neurophysiol 99:1616-1627. CrossRef Medline

Simons DJ (1978) Response properties of vibrissa units in rat SI somatosensory neocortex. J Neurophysiol 41:798-820. Medline

Song S, Sjöström PJ, Reigl M, Nelson S, Chklovskii DB (2005) Highly nonrandom features of synaptic connectivity in local cortical circuits. PLoS Biol 3:e68. CrossRef Medline

Sutter ML, Loftus WC (2003) Excitatory and inhibitory intensity tuning in auditory cortex: evidence for multiple inhibitory mechanisms. J Neurophysiol 90:2629-2647. CrossRef Medline

Sutter ML, Schreiner CE (1995) Topography of intensity tuning in cat primary auditory cortex: single-neuron versus multiple-neuron recordings. J Neurophysiol 73:190-204. Medline

Swadlow HA (2003) Fast-spike interneurons and feed-forward inhibition in sensory neocortex. Cereb Cortex 13:25-32. CrossRef Medline

Tan AY, Wehr M (2009) Balanced tone-evoked synaptic excitation and inhibition in mouse auditory cortex. Neuroscience 163:1302-1315. CrossRef Medline

Tan AY, Zhang LI, Merzenich MM, Schreiner CE (2004) Tone-evoked excitatory and inhibitory synaptic conductances of primary auditory cortex neurons. J Neurophysiol 92:630-643. CrossRef Medline

Tan AY, Atencio CA, Polley DB, Merzenich MM, Schreiner CE (2007) Unbalanced synaptic inhibition can create intensity-tuned auditory cortex neurons. Neuroscience 146:449-462. CrossRef Medline

Tanahira C, Higo S, Watanabe K, Tomioka R, Ebihara S, Kaneko T, Tamamaki N (2009) Parvalbumin neurons in the forebrain as revealed by parvalbumin-cre transgenic mice. Neurosci Res 63:213-223. CrossRef Medline

Thomson AM, Lamy C (2007) Functional maps of neocortical local circuitry. Front Neurosci 1:19-42. CrossRef Medline

Wang J, Caspary D, Salvi RJ (2000) GABA-A antagonist causes dramatic expansion of tuning in primary auditory cortex. Neuroreport 11:1137-1140. CrossRef Medline

Wang Y, Gupta A, Toledo-Rodriguez M, Wu CZ, Markram H (2002a) Anatomical, physiological, molecular and circuit properties of nest basket cells in the developing somatosensory cortex. Cereb Cortex 12:395-410. CrossRef Medline

Wang J, McFadden SL, Caspary D, Salvi R (2002b) Gamma-aminobutyric acid circuits shape response properties of auditory cortex neurons. Brain Res 944:219-231. CrossRef Medline

Watkins PV, Barbour DL (2011) Rate-level responses in awake marmoset auditory cortex. Hear Res 275:30-42. CrossRef Medline

Wehr M, Zador AM (2003) Balanced inhibition underlies tuning and sharpens spike timing in auditory cortex. Nature 426:442-446. CrossRef Medline

Wilson NR, Runyan CA, Wang FL, Sur M (2012) Division and subtraction by distinct cortical inhibitory networks in vivo. Nature 488:343-348. CrossRef Medline

Wu GK, Li P, Tao HW, Zhang LI (2006) Nonmonotonic synaptic excitation and imbalanced inhibition underlying cortical intensity tuning. Neuron 52:705-715. CrossRef Medline

Wu GK, Arbuckle R, Liu BH, Tao HW, Zhang LI (2008) Lateral sharpening of cortical frequency tuning by approximately balanced inhibition. Neuron 58:132-143. CrossRef Medline

Xu X, Roby KD, Callaway EM (2010) Immunochemical characterization of inhibitory mouse cortical neurons: three chemically distinct classes of inhibitory cells. J Comp Neurol 518:389-404. CrossRef Medline

Yang Y, DeWeese MR, Otazu GH, Zador AM (2008) Millisecond-scale differences in neural activity in auditory cortex can drive decisions. Nat Neurosci 11:1262-1263. CrossRef Medline

Yoshimura Y, Dantzker JL, Callaway EM (2005) Excitatory cortical neurons form fine-scale functional networks. Nature 433:868-873. CrossRef Medline 
Zariwala HA, Madisen L, Ahrens KF, Bernard A, Lein ES, Jones AR, Zeng H (2011) Visual tuning properties of genetically identified layer $2 / 3$ neuronal types in the primary visual cortex of cre-transgenic mice. Front Syst Neurosci 4:162. CrossRef Medline
Zhang LI, Tan AY, Schreiner CE, Merzenich MM (2003) Topography and synaptic shaping of direction selectivity in primary auditory cortex. Nature 424:201-205. CrossRef Medline 